\title{
Metamorphism of Jhyallaphay-Barpak-Bhachchek area of Gorkha District, Lesser Himalaya and Higher Himalaya, Central Nepal
}

\author{
*Lok Mani Oli ${ }^{1}$, Sameer Paudel ${ }^{2}$, and Lalu Prasad Paudel ${ }^{2}$ \\ ${ }^{1}$ Khani Khola (Dolakha) Hydropower Project (30 MW), Dolakha, Janakpur, Nepal \\ ${ }^{2}$ Central Department of Geology, Tribhuvan University, Kirtipur, Kathmandu, Nepal \\ *Corresponding author: oli.manilok90@gmail.com
}

\begin{abstract}
The study is focused on geological mapping, petrography and metamorphism of Jhyallaphat-Barpak-Bhachchek area, a part of Gorkha District, Central Nepal using a base of 1:25000 scale covering an area of $139.80 \mathrm{sq} . \mathrm{km}$. The rocks of the study area can be broadly divided into two tectonic zones; the Lesser Himalaya consisting of fie lithological units, and the Higher Himalaya consisting of Formation I of the Tibetan Slab. Three metamorphic zones can be distinguished in the study area; biotite zone, garnet zone and kyanite zone. The biotite zone of the mineral assemblage in pelitic rocks consists of biotite + muscovite + chlorite + quartz, in psammitic rocks comprises of biotite+muscovite+chlorite+feldspar+quartz and in carbonate rocks comprises of biotite + muscovite + calcite/dolomite + feldspar+quartz, respectively. These mineral assemblages show that the area belongs to the greenschist facies. The mineral assemblage of the garnet zone in pelitic rocks constitutes garnet+biotite + muscovite + chlorite + quartz, and in psammitic rocks constitutes of garnet+biotite+muscovite+feldspar+quartz. The minerals assemblages found within the biotite and garnet zones represent the well-known inverted metamorphism in the Lesser Himalaya. Mineral assemblage of the kyanite zones constitutes of kyanite+garnet+biotite+muscovite+feldspar+quartz. The mineral assemblages of the both garnet and kyanite zones show that the area belongs to the epidote amphibolite facies.

The bedding and foliation planes are almost parallel, showing that isograds also cut across the foliation. Therefore, the main metamorphic event should have followed development of foliation in the area. The rocks of the area show at least two metamorphic events: syntectonic prograde and post-tectonic retrograde. Syn-tectonic prograde metamorphism (M1), which has grown during a single phase of deformation and most frequently encountered garnet prophyroblast. Metamorphic deformation is represented by the presence of metamorphic foliation, stretching lineation, and S-C fabric. Post-tectonic retrograde metamorphism (M2), which is followed by retrograde mineral formation changing its $\mathrm{P}-\mathrm{T}$ condition from high to low grade minerals, such as the formation of the biotite and chlorite minerals around the rims of the garnet porphyroblasts.
\end{abstract}

Keywords: Inverted metamorphism, Garnet porphyroblast, Metamorphic Facies, Isograd, MCT Zone

Paper Received: 20 Dec 2018

Paper Accepted: 27 Mar 2019

\section{INTRODUCTION}

Himalaya was formed as a consequence of the collision of northward moving Indian continent with the Eurasian landmass at about Eocene period. Tectonically, the whole Himalaya can be divided into different longitudinal units, each having unique stratigraphic and evolutionary geological characteristics (Gansser, 1964). From south to north, the Himalayan belt is divided into different tectonic zones separated by major thrusts and normal fault namely; the Indo-Gangetic Plain, the Sub-Himalaya, the Lesser Himalaya, the Higher Himalaya, and the Tibetan-Tethyan Himalaya, respectively (Fig. 1). This Himalayan belt is also well known for its heterogeneous textures and structures as well as for inverted metamorphism (Dhital, 2015). The Main Central Thrust (MCT), one of the major thrusts separates the high grade metamorphic rocks of the Late Proterozoic metasedimentary and granitic rocks of the Higher Himalaya with the underlying low to medium grade metamorphosed early Proterozoic metasedimentary and large extent of clastic sediments with locally important carbonate rocks of the Lesser Himalaya. The Lesser Himalaya is the fold and thrust belt with complex stratigraphy and structure. It can be distinguished into a narrow outer and a broad inner or Midland sedimentary belt. Tectonic deformation is intense in the outer belt. Undisturbed sequences are more readily found in the broad open folds that characterize the Midland.

Many researchers worked in the Lesser Himalaya and the Higher Himalaya in different aspects like geological mapping, tectonics, petrographic study, metamorphism, geochronology and micro-tectonics during different time periods; although many geoscientists spent much time in west-central Nepal (Colchen et al., 1980, 1986; Le Fort, 1975; Pêcher, 1977, 1989; Hodges et al., 1988, 1996; Rai et al., 2005; Paudel and Arita, 2000; Paudyal and Paudel, 2011; Paudyal, 2018). Colchen et al. (1980, 1986), Le Fort (1975), and Pêcher (1977, 1989) have 


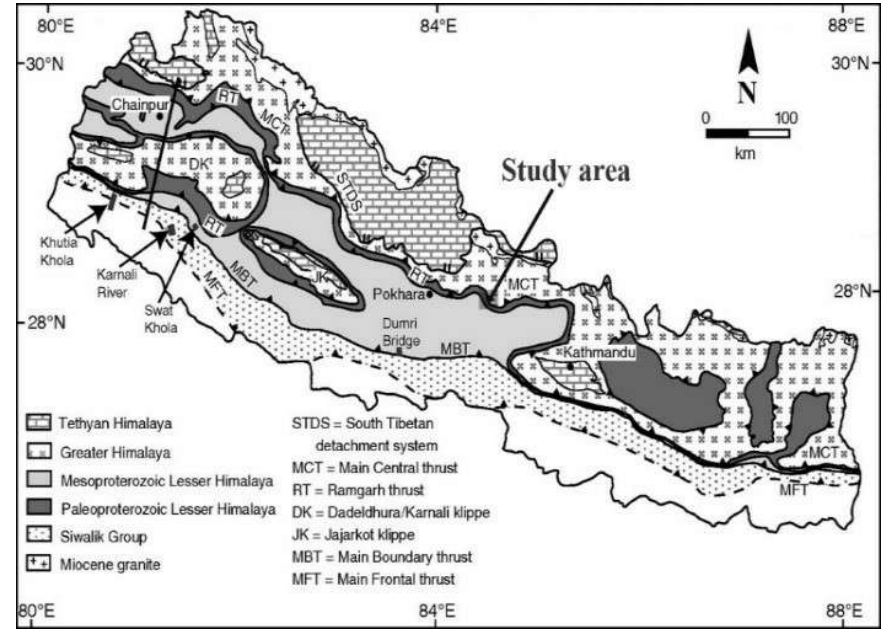

Fig. 1: Geological map of Nepal showing the location of the study area (modified after Amatya and Jnawali, 1994)

carried out detailed geological mapping along with the studies from different approaches of Annapurna-Manaslu-Ganesh Himal area, central-west Nepal.

The present study focuses on the geological mapping, petrography and metamorphism of high-grade metamorphic rocks of the Formation I of the Higher Himalaya and the mediumgrade metamorphic rocks of the Lesser Himalaya. These two tectonic zones are separated by the MCT. The presence of the MCT at the western part of the study area is confirmed by the presence of kyanite belonging to the rocks of the Higher Himalaya above the MCT, and at eastern part by a sharp contact of the underlying graphitic schist of the Lesser Himalaya with abrupt overlying banded gneiss of the Higher Himalaya.

\section{GEOLOGICAL SETTING}

The study area lies on southern west part from Jhallayaphat village, northern east Barpak village to western part of Bhachchek village of the Gorkha district, west - central Nepal (Fig. 1). The study area is located between the latitudes from $28^{\circ} 07^{\prime} 30^{\prime \prime}$ to $28^{\circ} 15^{\prime} 00^{\prime \prime} \mathrm{N}$ and longitudes from $84^{\circ} 39^{\prime} 00^{\prime \prime}$ to $84^{\circ} 46^{\prime} 15^{\prime \prime} \mathrm{E}$ covering an area of about $139.80 \mathrm{sq}$. $\mathrm{km}$. The rocks of the study area belong to the Nawakot Complex of the Lesser Himalaya and the Higher Himalaya (Fig. 2). The Lesser Himalaya comprises of medium-grade metamorphic rocks divisible into following units; namely as Calcareous Metasandstone and Marble, Psammitic Schist, Calcareous Quartzite and Psammitic Schist, Calcareous Quartzite and Marble, and Graphitic Schist from older to younger strata, respectively (Fig. 2). The Higher Himalaya consists of mediumto high-grade metamorphic rocks as Banded Gneiss interbedded with quartzite (Fig. 2). These two tectonic zones are distinctly separated by a thick ductile shear zone as the Main Central Thrust (MCT) zone. The MCT zone is predominantly assumed to have been most active at $22 \pm 20 \mathrm{Ma}$ (Hubbard and Harrison, 1989), acting as the location for at least $140 \mathrm{~km}$ of southward thrusting of the Higher Himalayan crystalline rocks (Schelling and Arita, 1991). Colchen et al. (1986) has prepared a geological map of Annapurna-Manaslu-Ganesh Himal area, and generalized lithostrtigraphic column of this section.

\section{METHODOLOGY}

Topographic map of the Barpak area (sheet No. 2884 15B) published by the Department of Survey, Government of Nepal in 1998 on a scale of 1:25,000 and the Arughat area (sheet No. 2884 16) in 1996 on a scale of 1:50,000 were used for the preparation of the base map of the geological mapping based on the rock types and GPS coordinates. Various lithological units were mapped along with their attitudes with detailed descriptions of the rocks. The measurement of the geological structures such as attitude of bedding plane, foliation plane and mineral lineation were also carried out during the field visit. All possible routes were used to observe the lithostratigraphy, geological structures, metamorphism and mineral resources of the area and to collect the necessary data. The samples were collected systematically covering the entire area. Oriented samples were taken to preserve the direction of strike in situ for the laboratory analysis. Out of them, 18 samples were used to make thin sections for studying mineral composition, and fabric in the laboratory. Final layout of geological map, geological cross-section and isograd map were prepared by using software ArcGIS (10.1).

\section{Lithostratigraphy}

The rocks of study area are tectonically divided into two zones: the Lesser Himalaya and the Higher Himalaya (Figs. 2 and 3). The Lesser Himalaya consists of calcareous quartzite, calcareous metasandstone, dolomitic marble, marble, pelitic and psammatic schist, graphitic schist, and metabasic rock interbedded with quartzite while the Higher Himalaya consists of the banded gneiss interbedded with quartzite (Figs. 2 and 3). The rocks consist of kyanite bearing high grade metamorphic rocks of the Formation I of the Tibetan Slab of the Higher Himalaya, overlie the underlying low to medium grade metamorphosed rocks of the Midland Formation of the Lesser Himalaya along the MCT (Le Fort, 1975). The Lesser Himalayan rocks can be correlated with the Midland Formation, centralwest Nepal (Le Fort, 1975; Pecher, 1978; Colchen et al., 1986); the Nawakot Complex in the central Nepal (Stöcklin and Bhattarai, 1977; Stöcklin, 1980); the Kaligandaki Super Group, West-central Nepal (Sakai, 1985). The rocks of the Nawakot Complex are overlain by the rocks of the Kathmandu Complex along the Mahabharat Thrust (Stöcklin and Bhattarai, 1977; Stöcklin, 1980).

\section{Higher Himalaya}

The rocks of the Higher Himalaya in the study area are composed of epidote-amphibolite facies metamorphic rocks. The Higher Himalaya in the study area is mapped into one unit on the basis of distinct lithology and association of minerals. 


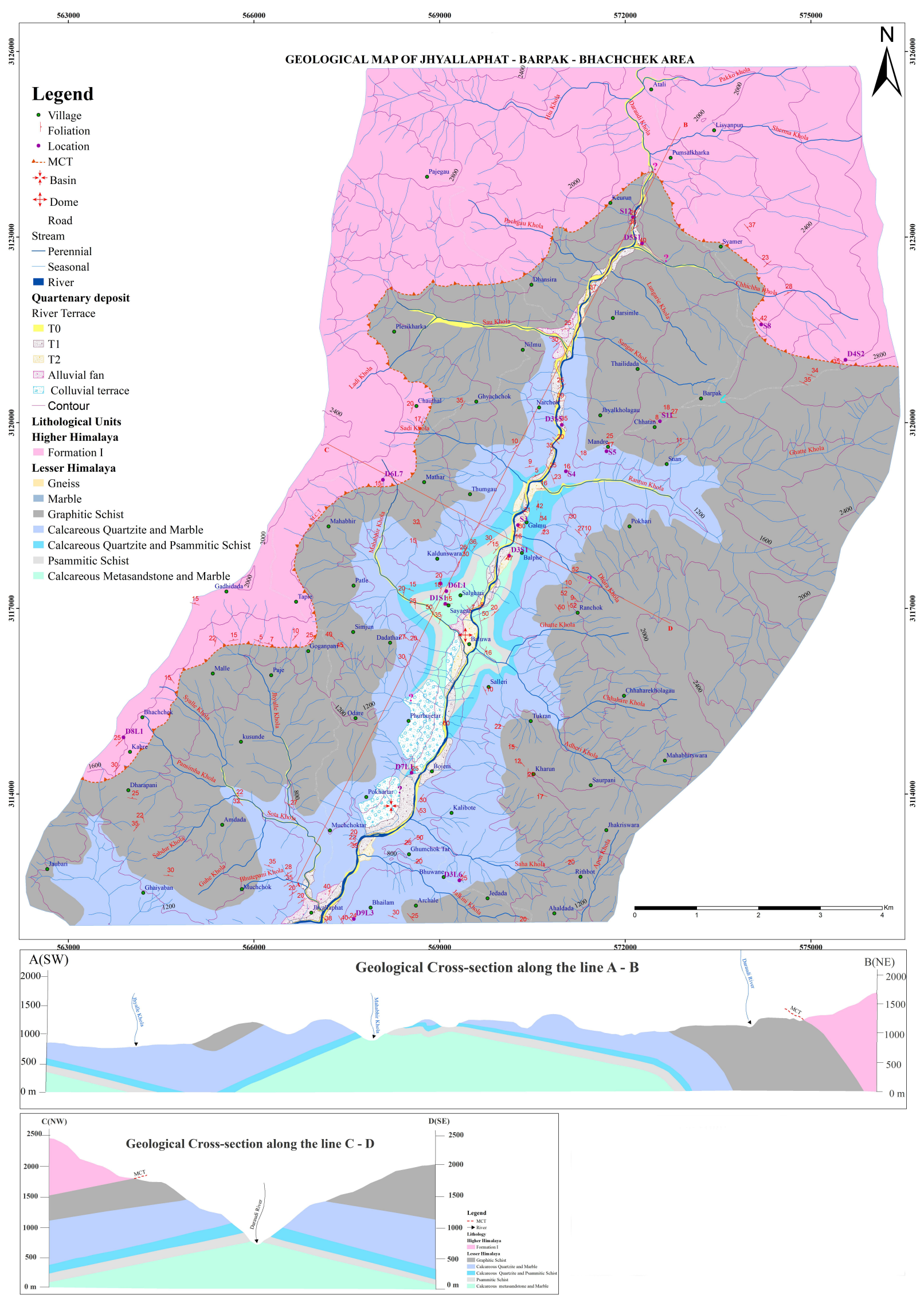

Fig. 2: Geological map of Jhyallaphat-Barpak-Bhachchek area 


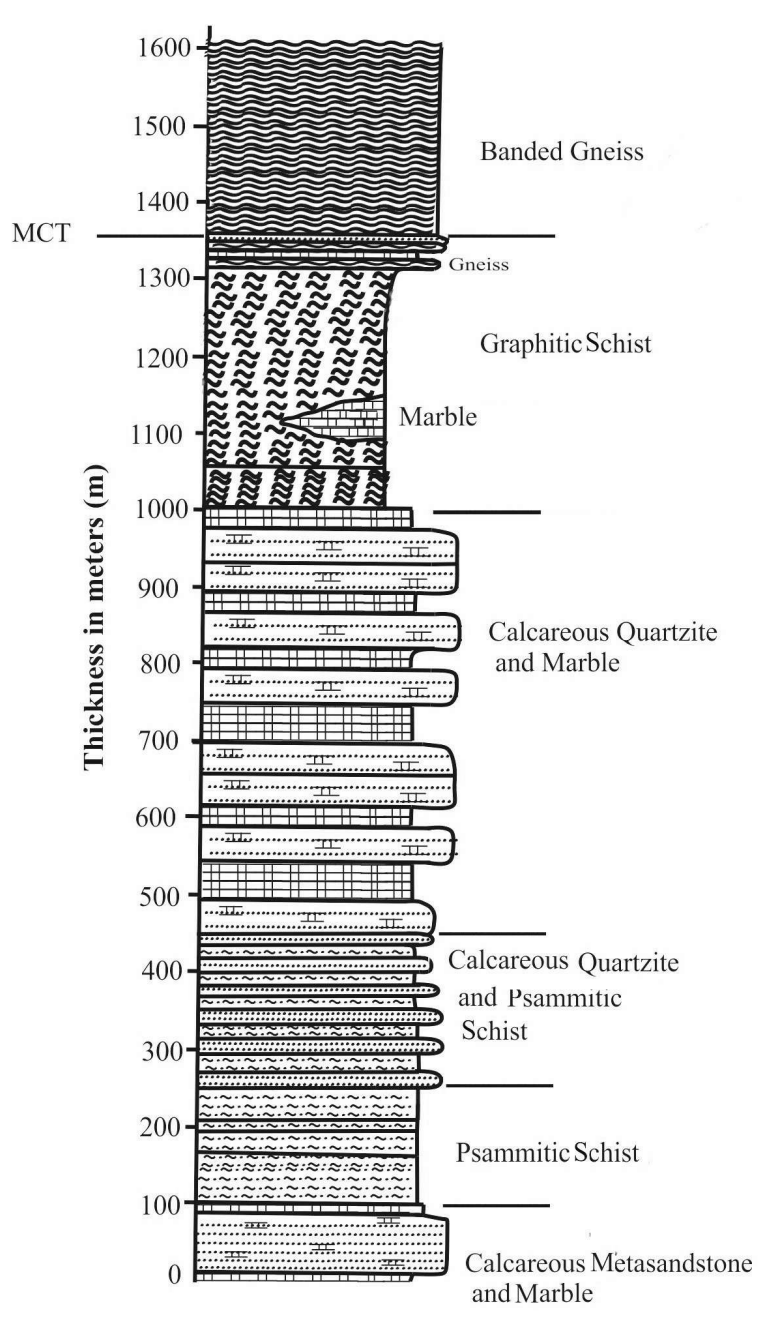

Fig. 3: Generalized columnar section of Khudi-Bahundanda area

This lithological unit is a Banded Gneiss and Quartzite which belongs to the Formation I of the Tibetan Slab (Le Fort, 1975; Colchen et al., 1980; 1986).

\section{Banded Gneiss and Quartzite of the Formation I}

This unit is well-exposed on the way to Larpak from Barpak, Mathar, Bhachehek, Taple, Ghyachchok, Bhalu kharka, and Simjung villages (Figs. 2 and 3). The exposure consists of interbands of dark color, thin to medium banded (ranging from 10-300 mm), slightly weathered, mica-rich gneiss and lightgrey banded gneiss with white color, medium to thick banded (ranging from 200-800 mm) quartzite (Fig. 4). Some parts of this unit consist of massive banded quartzite abundantly ranging its size from $1-5 \mathrm{~m}$ thick. Lenses of segregated quartz are differentiated from the dark minerals, which are common throughout this unit. Quartzite transitionally changes into garnetkyanite gneiss and abundant boudinage. Garnet grains are widespread in the rock exposure of this unit as compared to the kyanite.

\section{Lesser Himalaya}

This lithostratigraphy of the study area of the Lesser Himalaya is correlated with the stratigraphy of the Upper Midland Formations by Colchen et al. (1980). In this unit, rocks are composed of greenschist to epidote-amphibolite facies metamorphic rocks. Most of the rocks are calcareous. The Lesser Himalaya is represented by the following lithological units namely as Calcareous Metasandstone and Marble; Psammitic Schist; Calcareous Quartzite and Psammitic Schist; Calcareous Quartzite and Marble; and Graphitic Schist from bottom to top section, respectively (Figs. 2 and 3).

\section{Calcareous Metasandstone and Marble}

This unit is well-exposed at the left bank of the Mahabir Khola and the Andheri Khola nearby the Baluwa Bazar, and extends northward to $300 \mathrm{~m}$ down from the Galmu Village (Figs. 2 and 3). It is also well-exposed at Sayagau, Salghari and Mausuli and Jhulunge villages. This unit consists of white to light gray color, medium to thick banded (ranging from 100 to $600 \mathrm{~mm}$ ), coarse-grained, moderate weathered calcareous metasandstone with minor psammitic schist parting interlayered with white color, thin to medium banded (ranging from 30 to $300 \mathrm{~mm}$ ), coarse-grained, slightly weathered dolomitic marble. In some parts of this unit, rock consists of white to gray, thin to medium banded (ranging from 20 to $250 \mathrm{~mm}$ ), coarse-grained, slightly weathered calcareous quartzite and gray to light black color, thin banded (ranging from 20 to $100 \mathrm{~mm}$ ) coarse-grained, well foliated, moderately weathered psammitic schist.

\section{Psammitic Schist}

This unit is well-exposed on the road cut along BaluwaBarpak road section at E10570257 N03118206 to nearby Galmu and just upward at Salghari Village (Figs. 2 and 3). This unit consists of gray to grayish black, thin to medium banded (ranging from 30 to $300 \mathrm{~mm}$ ), coarse-grained, well foliated, moderately weathered, psammitic schist (relatively the content of biotite is more than muscovite but somewhere muscovite is relatively more) interlayered with gray color, thin banded (ranging from 50 to $100 \mathrm{~mm}$ ), coarse-grained, well foliated, moderately weathered calcareous metasandstone. At lower portion of this unit, psammitic schist is quite thicker than metasandstone while at upper part the psammitic schist and calc- metasandstone becomes almost equal. In some parts of this unit, the rock exposure shows abundant mineral stretching lineation.

\section{Calcareous Quartzite and Psammitic Schist}

This lithological unit is well-exposed in Baluwa-Barpak road section nearby Galmu Village to the confluence of Daraudi Khola and Rangrung Khola catchmaent area, Sallari, Bhugotoli and nearby Bhojeni villages (Figs. 2 and 3). This unit is characterized by gray to light gray, impure white to pink, thin to medium banded (ranging from 30 to $300 \mathrm{~mm}$ ), coarse-grained, 


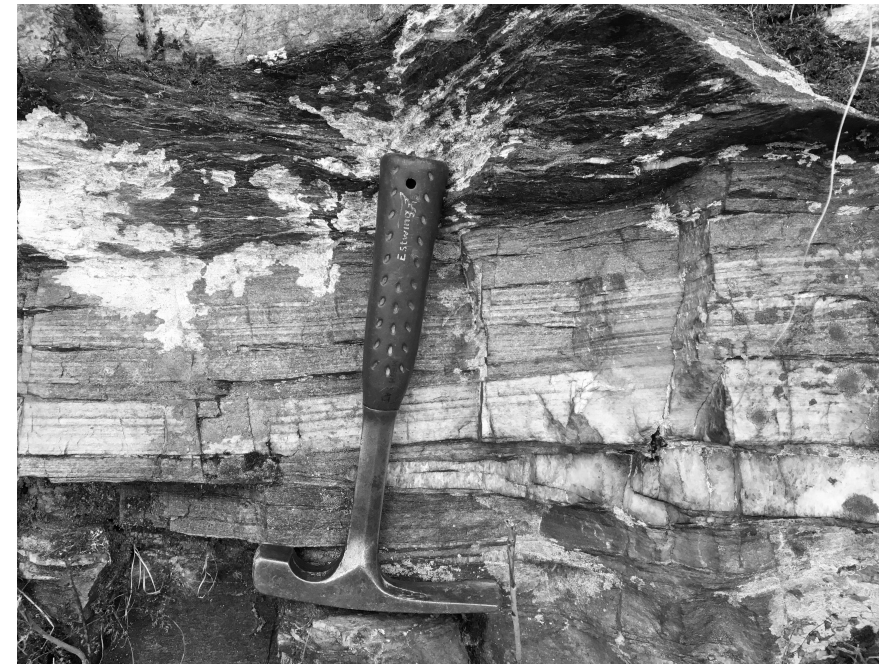

Fig. 4: Exposure of banded gneiss and quartzite near Mathar village (coordinate E568750, N3118980)

well foliated, slightly weathered, calcareous quartzite interbanded with pink to light pink, thin to thick banded (ranging from 30 to $550 \mathrm{~mm}$ ), coarse-grained, well foliated, moderately weathered psammitic schist.

\section{Calcareous Quartzite and Marble}

This unit is well-exposed at Jhyallaphat, Pokhatar, Gauthali, Kalibote, Narchok, Mandre, and Kaldunswara villages (Figs. 2 and 3). It is also well-exposed Daraudi River section at $100 \mathrm{~m}$ upstream from the confluence of the Rangrung and Daraudi Khola and a few meters upstream from confluence of Daraudi and Sau kholas. This unit is characterized by dirty white to white, medium to thick banded ranging from 0.3 to 2 $\mathrm{m}$ in size, coarse-grained, well foliated calcareous quartzite (Fig. 5). It also consists of white to grayish white, light blueish color, medium to thick banded (ranging from 0.2 to $1 \mathrm{~m}$ ), coarsegrained, well foliated, marble. Actinolite mineralization in the form of spot and thin layer (less than $5 \mathrm{~mm}$ ) is observed in banded calcareous quartzite.

\section{Graphitic Schist}

This unit is well-exposed at Barpak, Ghychok, Lamachhanitar, Phaplu, Dargauda, Sourpani, Ranchok, Polchari and Kalimiti villages. This unit consists of dark black, thin to medium banded ranging in size from 70 to $300 \mathrm{~mm}$, coarsegrained, well foliated, moderately weathered, graphitic schist, with well-developed of garnet grain $(2 \mathrm{~cm})$. At the Ranchowk Village rock consists of gray to bluish gray, medium to thick banded (ranging from 2 to $10 \mathrm{~m}$ ), coarse-grained, well foliated, slightly weathered marble. At the upper part of this unit from the confluences of Chhichca Khola and Daraudi Khola, rock consists of dark grey color, thick banded (ranging from 0.50 to $2 \mathrm{~m}$ ), coarse-grained, well foliated gneiss.

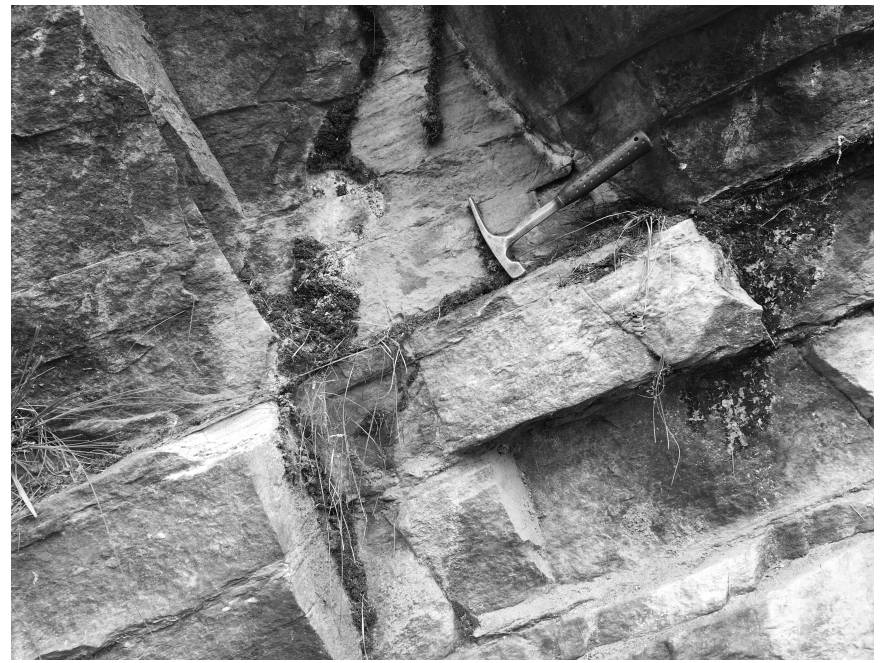

Fig. 5: Exposure of calcareous quartzite, $650 \mathrm{~m}$ upstream at left bank of the Daraudi Khola from the confluence of the Daraudi Khola and the Rangrung Khola

At about $200 \mathrm{~m}$ above right bank of the Daraudi Khola (downstream) from the confluences of Chhichca Khola and Daraudi khola, the rock exposure consists of green color, thin layered (ranging from 5 to $50 \mathrm{~mm}$ ), coarse-grained, slightly weathered metabasic rock (e. g. presence of actinolite mineral). The basic rock is interlayered with white to grayish white color, medium to thick banded (ranging from 0.25 to $1 \mathrm{~m}$ ), coarsegrained, well foliated, slightly weathered calcareous quartzite. An exposure of weathered gneiss is also observed interlayered with milky white, thick banded (ranging from 0.50 to $1 \mathrm{~m}$ ), coarse-grained quartzite with mica parting.

\section{COMPOSITION AND FABRIC OF ROCKS}

A brief petrographic description and photomicrograph of each sample are explained from older to younger strata, respectively.

\section{Higher Himalaya}

The Higher Himalaya comprises of Banded Gneiss and Quartzite belonging to the Formation I.

\section{Banded Gneiss and Quartzite}

The gneiss (sample D6L7) consists of the mineral assemblage of $\mathrm{Bt}$ (biotite)+Ms (muscovite)+Qtz (quartz) (Fig. $6)$. It consists of quartz $\sim 68 \%$, biotite $\sim 11 \%$, and muscovite ${ }^{\sim}$ $21 \%$. It consists of very fine- to fine-grained quartz (75-600 $\mu \mathrm{m})$ and biotite $(85-620 \mu \mathrm{m})$, and fine- to medium-grained muscovite $(400-1300 \mu \mathrm{m})$. Quartz is anhedral to subhedral. No kyanite was observed in this sample. Foliation is defined by preferred orientation of mica. One set of foliation is clearly visible and other deformation features are not so distinct. Tangential contact between quartz gains is common. 


\section{Lesser Himalaya}

The Lesser Himalaya consists of five lithological units from the bottom to the top, respectively.

\section{Calcareous Metasandstone and Marble}

The calcareous metasandstone (sample D3S1) consists of the mineral assemblage of $\mathrm{Bt}+\mathrm{Ms}+\mathrm{Chl}$ (chlorite) $+\mathrm{Cal}$ (calcite)+Fs(feldspar)+Qtz (Fig. 7). The sample constitutes quartz $\sim 42 \%$, feldspar $\sim 6 \%$, dolomite $\sim 30 \%$, mica $\sim 20 \%$ and chlorite $\sim 2 \%$. It consists of fine-grained quartz $(100-240 \mu \mathrm{m})$, feldspar $(80-200 \mu \mathrm{m})$, mica $(\sim 180 \mu \mathrm{m})$, chlorite $(\sim 160 \mu \mathrm{m})$ and dolomite $(\sim 80-220 \mu \mathrm{m})$. Most of the grains of quartz and feldspar are subhedral to anhedral in shape, although dolomite has anhedral shape. Indented grain contacts between quartz grains are common. Foliation is defined by preferred orientation of mica and elongated quartz. One set of foliation is clearly visible.

\section{Psammitic Schist}

The psammitic schist (sample D6L1) consists of the mineral assemblage of $\mathrm{Bt}+\mathrm{Ms}+\mathrm{Fs}+\mathrm{Qtz}$ (Fig. 8). The sample consists of quartz $\sim 60 \%$, feldspar $\sim 5 \%$, biotite $\sim 10 \%$ and muscovite $\sim 25 \%$. Quartz is fine-grained $(100-600 \mu \mathrm{m})$. Grain size of feldspar is $80-350 \mu \mathrm{m}$, biotite is about $180-1000 \mu \mathrm{m}$ and muscovite is about 200-1200 $\mu \mathrm{m}$. The grain shapes of quartz and feldspar are anhedral. Mica are elongated and generally fine-grained. Foliation is defined by the preferred orientation of mica. Granoblastic texture of quartz is commonly seen and tangential contact between quartz gains is common. Some grains show suture contact.

\section{Calcareous Quartzite and Psammitic Schist}

The psammitic schist (D7L1) constitutes the mineral assemblage of $\mathrm{Bt}+\mathrm{Ms}+\mathrm{Qtz}$ (Fig. 9). The sample contains quartz $\sim 77 \%$, biotite $\sim 13 \%$ and muscovite $\sim 10 \%$. It consists of fineto medium-grained quartz $(160-1800 \mu \mathrm{m})$. Muscovite and biotite have size of about 200-2000 $\mu \mathrm{m}$ and about 180-2100 $\mu \mathrm{m}$, respectively. Quartz grains have subhedral to anhedral shape. Foliation is defined by the preferred orientation of mica. Granoblastic texture of quartz is commonly seen. Tangential contact between quartz gains is common. One set of foliation is clearly visible and other deformation features are not so distinct.

\section{Calcareous Quartzite and Marble}

The calcareous quartzite (sample D3S5) consists of the mineral assemblage of $\mathrm{Bt}+\mathrm{Ms}+\mathrm{Cal}+\mathrm{Qtz}$ (Fig. 10). The sample constitutes quartz $80 \%$, biotite $\sim 3 \%$, muscovite $\sim 7 \%$ and calcite $\sim 10 \%$. Quartz grains are fine (about 80-400 $\mu \mathrm{m}$ ). Similarly, muscovite $(100-500 \mu \mathrm{m})$, biotite $(\sim 80-400 \mu \mathrm{m})$ and calcite is about $(\sim 100 \mu \mathrm{m})$ all are fine. Quartz grains are anhedral to subherdal while calcites are anhedral. Foliation is defined by preferred orientation of mica. Granoblastic texture is commonly seen. The contact between quartz grains boundaries are usually suture. One set foliation is clearly visible and other deformation features are not so distinct.

The marble (sample D3L6) comprises of the mineral assemblage of $\mathrm{Ms}+\mathrm{Cal}+\mathrm{Qtz}$. The sample constitutes quartz ${ }^{\sim}$ $2 \%$, muscovite $\sim 1 \%$ and calcite $\sim 97 \%$. It consists of very fineto fine-grained quartz $(70-300 \mu \mathrm{m})$, fine-grained muscovite (about $\sim 180 \mu \mathrm{m}$ ) and medium to coarse-grained calcite (about $600-2900 \mu \mathrm{m})$. Grains of quartz are anhedral in shape and those of calcite are anhedral to subhedral. Twinnings are clearly visible on calcite.

\section{Graphitic Schist}

The garnet schist (sample S11) consists of the mineral assemblage of Grt(garnet) $+\mathrm{Bt}+\mathrm{Ms}+\mathrm{Fs}+\mathrm{Qtz}$, and comprises of quartz $\sim 26 \%$, muscovite $\sim 29 \%$, biotite $33 \%$, garnet 10\% and feldspar $\sim 2 \%$. The grain size of garnet is about 1100-1440 $\mu \mathrm{m}$, quartz (about 80-400 $\mu \mathrm{m}$ ), feldspar (about 90-380 $\mu \mathrm{m}$ ), muscovite (about 100-600 $\mu \mathrm{m}$ ) and that of a biotite is about $100-580 \mu \mathrm{m}$. The grains of garnet, quartz and feldspar have an anhedral shape. Foliation is defined by the preferred orientation of mica and elongated quartz. One set of foliation is clearly visible. Quartz and mica are as inclusion in garnet.

The gneiss (sample D5S1) consists of the mineral assemblage of Grt+Bt+Ms+Fs+Qtz (Fig. 11), and constitutes quartz $\sim 37 \%$, biotite $\sim 19 \%$, muscovite $\sim 36 \%$ garnet $\sim 5 \%$ and feldspar $\sim 3 \%$. It consists of fine grains of quartz (about 100-600 $\mu \mathrm{m}$ ), feldspars (about 85-175 $\mu \mathrm{m}$ ), muscovite (about 100-800 $\mu \mathrm{m}$ ), biotite (about 100-750 $\mu \mathrm{m}$ ) and medium grains of garnet $(\sim 1620 \mu \mathrm{m})$. Grains of quartz, feldspar and garnet have anhedral shape. Foliation is defined by the preferred orientation of mica and elongated quartz. One set foliation is clearly visible. Garnet shows porphyroblastic texture with zonal distribution of quartz and mica inclusion. Grain in the garnet porphyroblast seems to be rotated showing the pressure shadow. The rim of the garnet is encircled by biotite and chlorite alteration showing the result of retrogression.

\section{METAMORPHISM}

The MCT is a major syn- to post-collisional thrust fault extending throughout most of the Himalayan range discussed in Rai et al. (1998). Some authors also appreciate another thrust not far below the MCT called as MCTI (Arita, 1983), Shrivastava and Mitra, 1994). The grade of metamorphism increases structurally upward to upper amphibolite and granulite facies from the hanging-wall of the MCT (Le Fort, 1975; Pecher, 1978; Hubbard, 1989; Macfarlane, 1995; Rai et al., 1998). The upper part of the Higher Himalaya Crystalline and part of the Tethyan Sedimentary Series are intruded by Miocene age leucogranites (Gansser, 1964; Le Fort, 1975). In central Nepal, the rocks of the Lesser Himalaya below the MCT show a gradual increase in metamorphic grade from chlorite, approximately 10 $\mathrm{km}$ below the MCT, to kyanite + staurolite grade close to the MCT (Pecher, 1978; Colchen et al., 1980; Rai et al., 1998). 


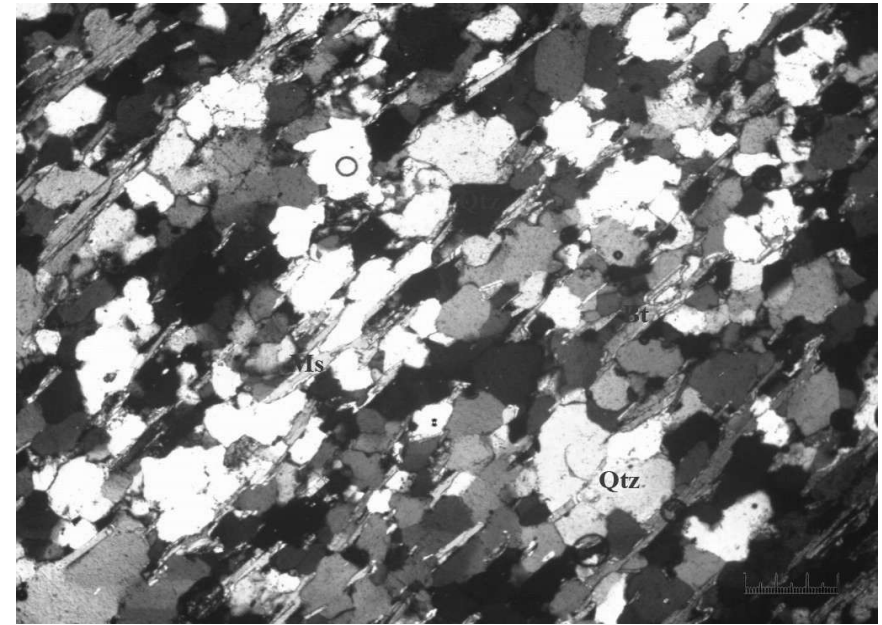

Fig. 6: Photomicrograph of gneiss with one-set of foliation (Sample no: D6L7). Scale: 1 division $=0.2 \mathrm{~mm}$

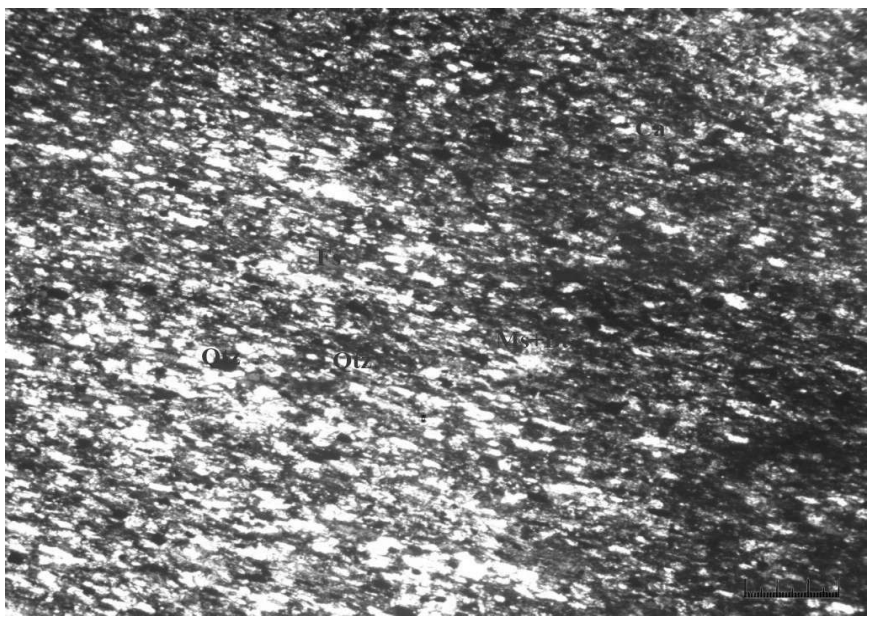

Fig. 7: Photomicrograph of calc. metasandstone showing one-set of foliation and elongated quartz (Sample no: D3S1). Scale: 1 division $=0.2 \mathbf{~ m m}$

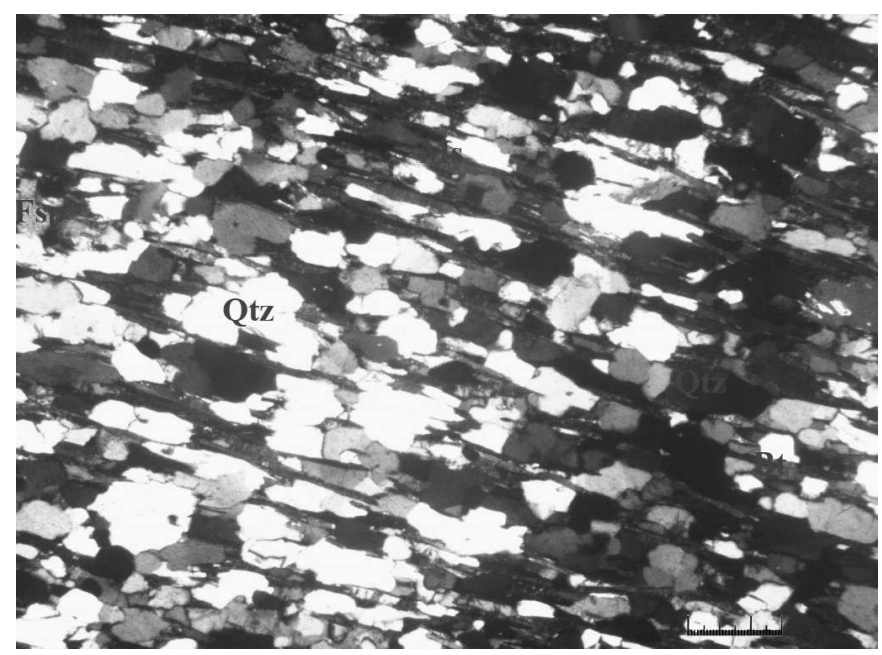

Fig. 8: Photomicrograph of psammitic schist showing suture contact and one-set of foliation (Sample no: D6L1). Scale: 1 division $=0.2 \mathrm{~mm}$

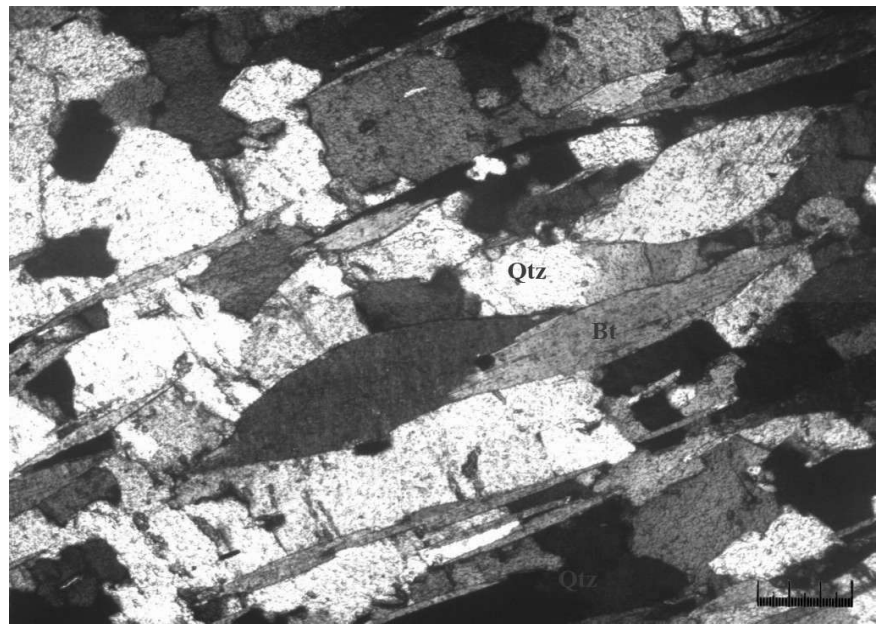

Fig. 9: Photomicrograph of psammatic schist showing oneset of foliation (Sample no: D7L1). Scale: $1 \mathrm{div} .=0.2 \mathrm{~mm}$

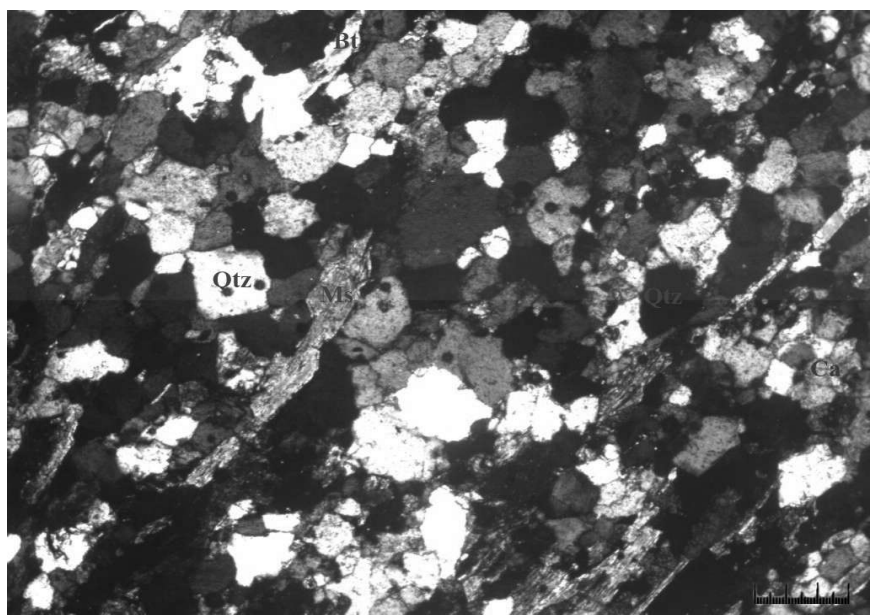

Fig. 10: Photomicrograph of calcareous quartzite showing suture contact and one-set of foliation (Sample no: D3S5). Scale: 1 division $=0.2 \mathrm{~mm}$

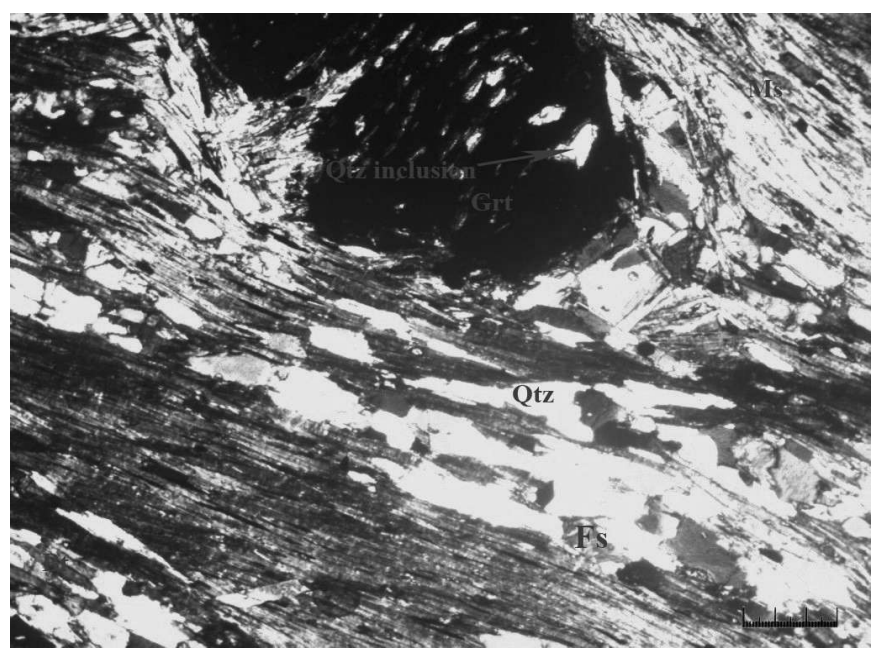

Fig. 11: Photomicrograph of zonal distribution of quartz inclusions in the garnet porphyroblast and presence of pressure shadow (Sample no: D5S1). Scale: $1 \mathrm{div} .=0.2 \mathrm{~mm}$ 
Caby et al. (1983) found no apparent metamorphic discontinuity immediately across the MCT in several sections of central Nepal. However, in eastern Nepal along the Everest-Makalu section, Brunel and Kienast (1986) assimilated a major metamorphic break along the MCT where kyanite grade rocks of Higher Himalayan Crystallines directly overlie chlorite grade rocks of the Lesser Himalaya.

The Lesser Himalaya in the study area consists of the greenschist to epidote amphibolite facies showing the inverted metamorphic gradient while the Higher Himalaya consists of the epidote-amphibolite metamorphic facies. Three typical metamorphic zones/isograds, with inverted sequence belonging to the Barrovian-type metamorphic sequence of regional metamorphism are well observed in the study area (Fig. 12).

\section{Metamorphic Zonation}

The study area is identified by three metamorphic zones on the basis of index minerals; they are biotite, garnet and kyanite zones, from the lower to the upper sections, respectively.

\section{Biotite Zone}

This zone is widely distributed at southern part of Jhyallaphat, Olan and Saurpani to north- north east Mandre, north-west at Dewalswara area. Biotite as index mineral is well observed in the rocks of Calc Metasandstone and Marble; Psammitic Schist; Calc Quartzite and Psammitic Schist; Calc Quartzite and Marble; and lower portion of Graphitic Schist of the Lesser Himalaya. The grain size of biotite increases from south to north. The mineral assemblage of pelitic rock is $\mathrm{Bt}+\mathrm{Ms}+\mathrm{Chl}+\mathrm{Qtz}$; psammitic rock of $\mathrm{Bt}+\mathrm{Ms}+\mathrm{Chl}+\mathrm{Fs}+\mathrm{Qtz}$ and carbonate rocks of $\mathrm{Bt}+\mathrm{Ms}+\mathrm{Cal} / \mathrm{Dol}+\mathrm{Fs}+\mathrm{Qtz}$.

\section{Garnet Zone}

This zone is widely distributed at the western part of Simjun, Malla, Dharapani, Patle and north east part of the Barpak Villages (Fig. 12). The zone extends from the middle part of graphitic schist of the Lesser Himalaya up to MCT Zone. The presence of garnet mineral is distributed to the proximity of the MCT. The grain size of garnet ranges from 0.5 to $1.5 \mathrm{~cm}$ in hand specimens and up to $1620 \mu \mathrm{m}$ in thin section. The mineral assemblages of this zone are $\mathrm{Grt}+\mathrm{Bt}+\mathrm{Ms}+\mathrm{Chl}+\mathrm{Qtz}$ in the pelitic rock, and $\mathrm{Grt}+\mathrm{Bt}+\mathrm{Ms}+\mathrm{Chl}+\mathrm{Fs}+\mathrm{Qtz}$ in the psammatic rock. The garnet size increases towards north approaching the MCT in the study area. In thin section, garnets are both rotated and non-rotated, the rotated garnets contain inclusion of quartz and mica.

\section{Kyanite Zone}

This zone is distributed at the southern west part nearby Bhachchek and Namki area (Fig. 12). The banded gneiss and quartzite of the Higher Himalaya consist of abundant kyanite with garnet. Grain size of kyanite ranges from 10 to $40 \mathrm{~mm}$ long and that of garnet from 4 to $10 \mathrm{~mm}$ in hand specimen. The mineral assemblages of this zone are Kyt (kyanite) $+\mathrm{Grt}+\mathrm{Bt}+\mathrm{Ms}+\mathrm{Fs}+\mathrm{Qtz}$. The size of kyanite increases towards the upper section of the Formation I of the Higher Himalaya.

\section{Metamorphic Facies}

From the metamorphic zonation described above and the mineral assemblages given below, the rocks of the study area belong to mainly two metamorphic facies (Table 1); the greenschist facies and epidote-amphibolite facies. The greenschist facies comprises biotite zone having mineral assemblages of $\mathrm{Bt}+\mathrm{Ms}+\mathrm{Chl}+\mathrm{Qtz}$ in the pelitic rock, $\mathrm{Bt}+\mathrm{Ms}+\mathrm{Chl}+\mathrm{Fs}+\mathrm{Qtz}$ in the psammitic rock and $\mathrm{Bt}+\mathrm{Ms}+\mathrm{Cal} / \mathrm{Dol}+\mathrm{Fs}+\mathrm{Qtz}$ in the carbonate rock. The epidot-amphiblolite facies is characterized by garnet zone and kyanite zone. The mineral assemblages of epidotamphiblolite facies are $\mathrm{Kyt}+\mathrm{Grt}+\mathrm{Bt}+\mathrm{Ms}+\mathrm{Chl}+\mathrm{Qtz}$ in the pelitic rock and $\mathrm{Kyt}+\mathrm{Grt}+\mathrm{Bt}+\mathrm{Ms}+\mathrm{Chl}+\mathrm{Fs}+\mathrm{Qtz}$ in the psammitic rock.

\section{Metamorphic Events}

Himalayan region is affected by poly-phase deformation and metamorphism (Paudel and Arita, 2000). The study of foliation and characteristics of the porphyroblasts of the minerals in the thin section and field observation show that the study area has encountered at least two metamorphic events, which can be distinguished as syn-tectonic prograde metamorphism (M1) and post-tectonic retrograde metamorphism (M2). Syntectonic prograde metamorphism (M1), which has grown during a single phase of deformation and is most frequently, encountered type of prophyroblast in nature (Fig. 16). The most characteristic syntectonic porphyroblast form when growth and strain rates are of the same order of magnitude. Inclusion pattern are generally curve. Metamorphic deformation is represented by the presence of metamorphic foliation, stretching lineation, and S-C fabric. Post-tectonic retrograde metamorphism (M2), which is followed by retrograde mineral from high to low grade such as garnet to biotite to chlorite (Fig. 11). Samples S11 and D5S1 contain the garnet porphyroblasts, respectively (Fig. 11). These samples consist of rotated garnet porphyroblasts with inclusion of recrystallized quartz and mica. In rotated garnet (sample S11) helictic folds are common and the porphyroblast consists of anhedral shape. In this sample, the inclusion pattern of garnet porphyroblast is identical to and continuous with the external foliation. Hence, these garnet prophyroblasts reveal the syntectonic prograde metamorphic event. Similarly, sample D5S1 in which the chemical zoning can be observed at the rim of these garnet prophyroblasts. At the rim of garnet prophyroblast, the garnet shows its retrogression to biotite and chlorite due to decreasing of the P-T conditions, which revealed the posttectonic retrograde event (Fig. 11). The garnets are pre-mylonitic skeletal porphyroblasts that rotated during mylonitic deformation. It follows that the asymmetry of the density distribution must result from the deformation history itself. Analysis of the rotation angles with aspect ratio of the garnet porphyroblasts demonstrates that a pure shear component was involved in an essentially noncoaxial flow. This may explain the internal asymmetry of the 


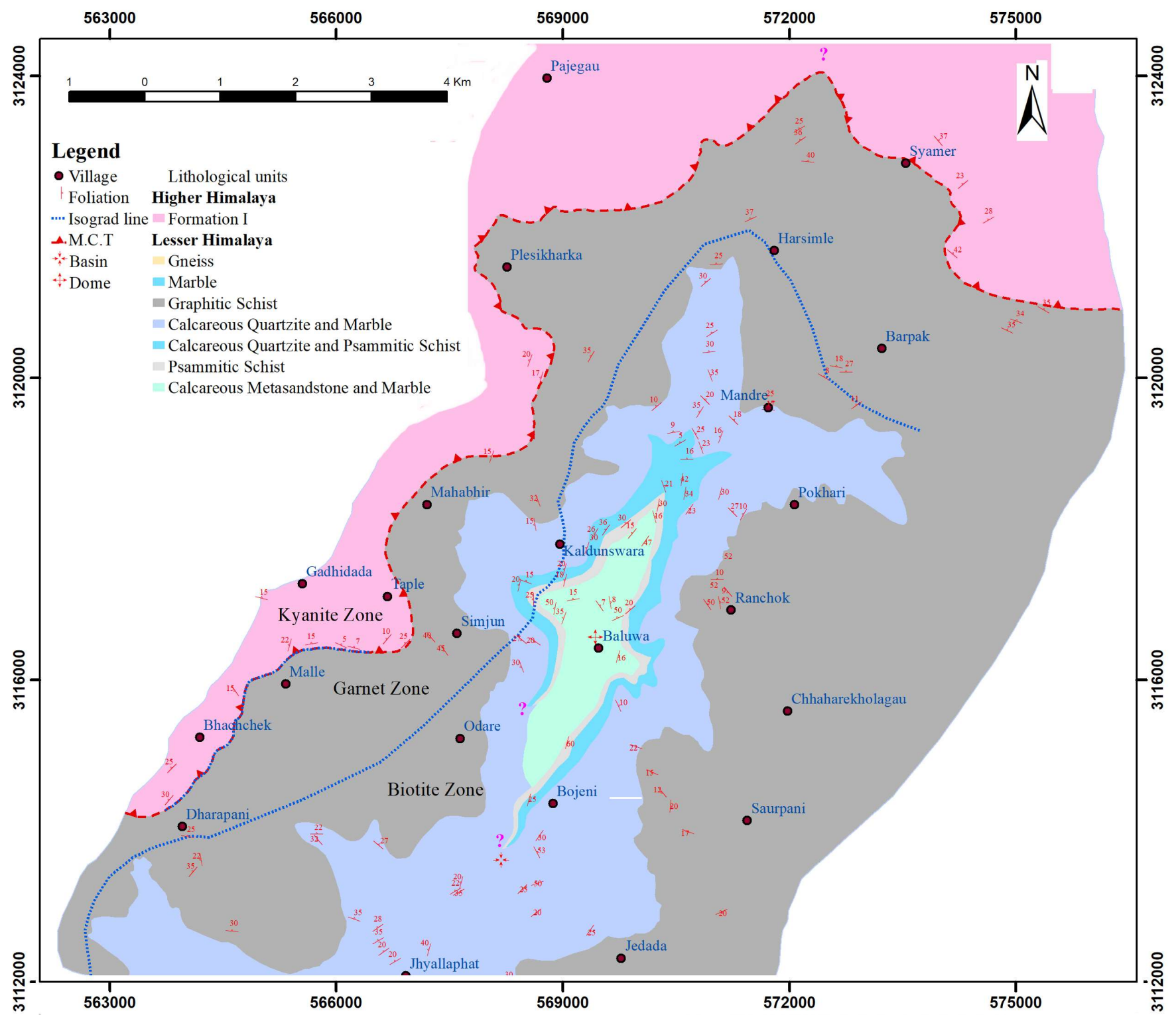

Fig. 12: Isograd map of the study area

fabric skeleton, and confirms the idea that a spectrum exists of type I fabrics intermediate between the theoretically predicted fabrics for pure and simple shear.

\section{Pressure - temperature conditions}

Le Fort et al. (1986) observed a temperature up to $7200 \mathrm{C}$ above the MCT, based on the Ga-Bt geothemometry and the rim pairs of the same geothermometry is reported to show 5300C (Vannay and Hodges, 1996) along the Kaligandaki section, western Nepal. The temperature is supposed to reflect the pre-MCT M1 metamorphic conditions and the latter, synMCT to post MCT M2 conditions recorded. Along the MCT Zone and the lower part of the Higher Himalaya two successive metamorphic events are recorded. The Ml (eo-Himalayan) corresponds to a progressive temperature increase from about $550^{\circ} \mathrm{C}$ to locally higher than $7000 \mathrm{C}$ with the pressure condition ranging from 550 to $900 \mathrm{MPa}$ (Le Fort et al., 1986). The M2 neo-Himalayan metamorphic event exhibits west to east pressure increase from $650 \pm 30 \mathrm{MPa}$ to $865 \pm 100 \mathrm{MPa}$ whereas the temperature increases from $540 \pm 650^{\circ} \mathrm{C}$ to $605 \pm 100^{\circ} \mathrm{C}$ (Pecher, 1989). Rai et al. (1998) also discussed P-T conditions (T: 540 $-615^{\circ} \mathrm{C}$; P: 405-790 MPa) estimated in the Gosainkund Crystalline Nappe (GCN), an equivalent of the Higher Himalaya and the Lesser Himalaya of the Kathmandu region $\left(\mathrm{T}: 530^{\circ} \mathrm{C}\right.$ and P:745 MPa) are similar to those observed in Kaligandaki Valley section, west-central Nepal. The pressure estimates obtained by the Thermocalc calibration method are plotted across the structural distance to the MCT which shows that the pressure gradually decreased from the MCT to the upper section 


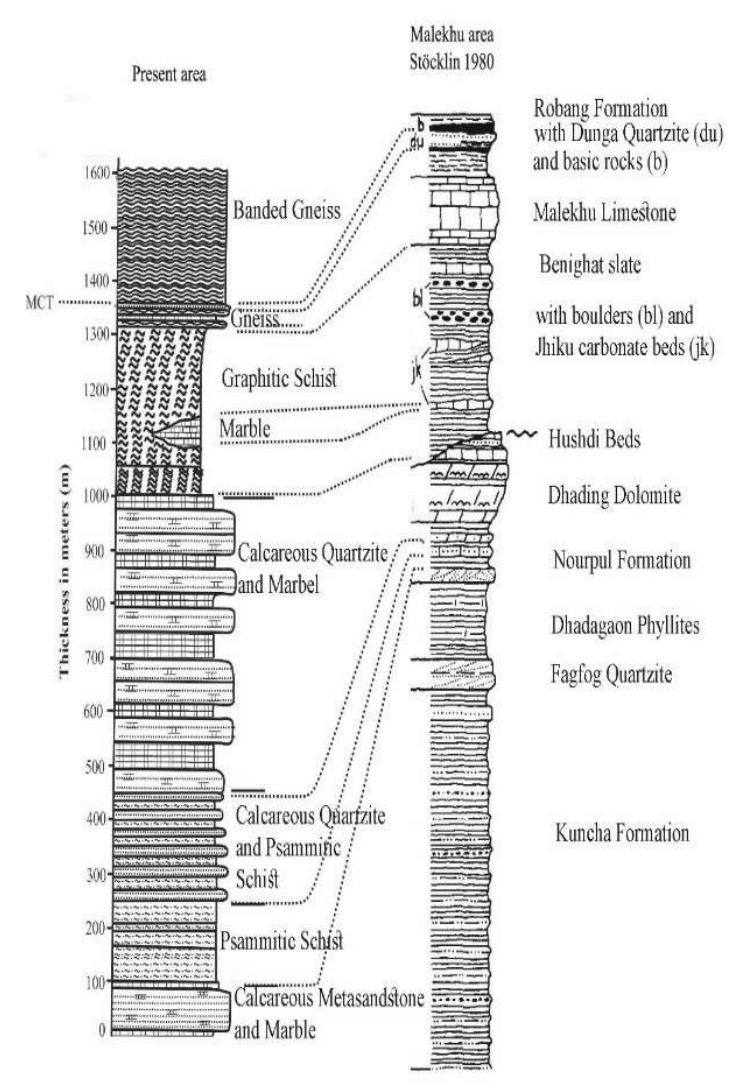

Fig. 13: Correlation of rocks from Jhyallaaphat-BarpakBhachchek with those from Central Nepal Lesser Himalaya (Stöcklin, 1980)

of the GCN (Rai et al., 1998). A similar pattern of decreasing pressure above the MCT has also been noted by Le Fort et al. (1986), Vannay and Hodges (1996) in the Kali Gandaki section, west-central Nepal; Macfarlane (1995) in the Langtang region, central Nepal. The present study does not have the P-T results; however, the study area is located between the Kaligandaki Valley section to the west and the Kathmandu region to the east. The P-T results of the study area could be similar to the results obtained by Rai et al. (1998) in the Kathmandu region, Macfarlane (1995) in the Langtang region to the east and Le Fort et al. (1986), Vannay and Hodges (1996) in the Kali Gandaki section to the west.

\section{DISCUSSION}

The lithostratigraphy of the study area is similar to the sequence of the Nourpul Formation, Dhading Dolomite and Benighat Slate from bottom to top sections, respectively, of the central Nepal (Stocklin, 1980). The study area consists of greenschist to epidote-amphibilite facies metamorphic rocks. Hence, there are no any significant primary structures preserved. The inner zone of the Lesser Himalaya is characterized by mega scale fold. The Kuncha Formation of the Lesser Himalaya is exposed in the core of the Great Midland Antiform, also known as Gorkha-Kuncha anticlinorium (after Ohta et al., 1973). The study area lies in both northern and southern limbs of the Gorkha-Kuncha anticlinorium. The establishment of stratigraphic position on the southern limb of the fold in the Lesser Himalaya was carried out by Stöcklin and Bhattarai (1977) and Stöcklin (1980). They divided the area into following stratigraphic units namely: Kuncha Formation, Fagfog Quartzite, Dandagaon Phyllites, Nourpul Formation, Dhading Dolomite, Benighat Slates, Malekhu Limestone and Robang Formation from older to younger, respectively. In the northern limb of anticlinal fold the lithology in the Nourpul Formation has been affected by comparatively high grade metamorphism due to thrusting of the MCT over the Lesser Himalayan rocks. At the southern limb of the anticlinal fold, the Nourpoul Formation has preserved the mud cracks in pelitic rocks due to low grade metamorphism and deformation (Fig. 13), similar to the sequence repeated in the northern limb. Some lithological characteristics such as pink calcareous quartzite interbedded with pink psammitic schist of the study area can be compared with the pink quartzitic and calcareous intercalation of micaceous phyllite of the Nourpul Formation (Stöcklin and Bhattarai, 1977). The dolomite and dolomitic quartzite interlayered become more abundant in the Upper Member of the Nourpul Formation, similar to calcareous quartzite of the study area.

Stratigraphically, the Dhading Dolomite is followed by the Nourpul Formation in southern limb. The Dhading Dolomite consists of dolomite and siliceous dolomite and lenticular bands of chert. Stromatolitic structure is the key feature of the Dhading Dolomite. Dolomite, siliceous dolomite and chert have been metamorphosed to calcareous quartzite and marble and no stromatolitic structure is preserved.

The Benighat Slate consists of dark bluish-gray to black, soft-weathering, and highly cleaved slate and phyllite. Graphitic schist shows similarity with the Benighat Slate. Due to metamorphism slate, phyllite has been metamorphosed to graphitic schist. It contains dark black graphitic schist to dark grey pelitic schist. Middle part of the Benighat Slate consists of the Jhiku Carbonates Bed, which are red by a variety of lithotypes. Some of them are thinly bedded, very fine-grained, dense, dark gray to black siliceous dolomite interbedded with black slates. Bluish grey limestone beds are exposed only at the Ranchok Village which can be correlated with the Jhiku Carbonate bed. The upper part of graphitic schist consists of few meter thickness of gneiss which can be correlated as the Lesser Himalayan Ulleri Gneiss. The lithostratigraphic units of Jhyallaaphat-Barpak-Bhachchek are correlated with the stratigraphy from Central Nepal Lesser Himalaya established by Stöcklin and Bhattarai (1977), Stöcklin (1980) (Fig. 13).

The metamorphism of the area on the basis of the petrographic study, mineral assemblage of the mineral zonation and field observation shows that the Lesser Himalayan rocks have been affected by the inverted gradient metamorphism increasing the P-T conditions from the lower section to the upper structural section approaching the MCT (from the biotite 
zone to the garnet zone), similar observation of the other regions of the Lesser Himalaya. Following the observations of the garnet porphyroblasts, syn-tectonic prograde metamorphism (M1) and post-tectonic retrograde metamorphism (M2) have been recorded in the study area.

\section{CONCLUSIONS}

The Banded Gneiss and Quartzite of the Formation I of the Higher Himalaya consists of the epidote-ampholite facies metamorphic rocks such as pelitic gneiss and quartzite. The Lesser Himalaya is divided into five lithological units on the basis of lithology viz, Calcareous Metasandstone and Marble, Psammitic Schist, Calcareous Quartzite and Psammitic Schist, Calcareous Quartzite and Marble, and Graphitic Schist from the older to the younger strata, respectively.

The Higher Himalaya consists of mainly the mineral assemblage of pelitic rocks such as gneiss $(\mathrm{Kyt}+\mathrm{Grt}+\mathrm{Bt}+\mathrm{Ms}+\mathrm{Fs}+\mathrm{Qtz})$. The Lesser Himalaya consists of the mineral assemblages of pelitic rocks $(\mathrm{Grt}+\mathrm{Bt}+\mathrm{Ms}+\mathrm{Chl}+\mathrm{Qtz})$, psammitic rocks $(\mathrm{Grt}+\mathrm{Bt}+\mathrm{Ms}+\mathrm{Chl}+\mathrm{Fs}+\mathrm{Qtz})$ and carbonate $\operatorname{rocks}(\mathrm{Bt}+\mathrm{Ms}+\mathrm{Cal} / \mathrm{Dol}+\mathrm{Fs}+\mathrm{Qtz})$.

The isograd boundary shows oblique relation with lithological boundary and with bedding and foliation, which show that the main metamorphism event should have been occurred after the foliation development in the area.

The rocks have been metamorphosed to greenschist facies and epidote-amphibolite facies in the Lesser Himalaya and epidote-amphibolite facies with the inverted metamorphic gradient. Two metamorphic events namely as syn-tectonic prograde metamorphism (M1) and post-tectonic retrograde (M2) have been identified from the study area.

\section{ACKNOWLEDGEMENTS}

The authors are thankful to Dr. Dinesh Pathak, Associate Professor and Director of Geo-disaster Research Centre, Central Department of Geology for providing the financial support for the filed survey and Central Department of Geology for providing the Laboratory facilities. The authors are also thankful to two anonymous reviewers for the providing the fruitful comments on our manuscript.

\section{REFERENCES}

Amatya, K.M. and Jnawali, B.M., 1994, Geological map of Nepal. Scale: 1:1000 000. Published by Department of Mines and Geology, International Centre for Integrated Mountain Development, Carl Duisberg Gesellschaft E. V., and United Nations Environment Programme, Berlin.

Amatya, K.M. and Jnawali, B.M., 1994, Geological map of Nepal. Scale: 1:1000 000. Published by Department of Mines and Geology, International Centre for Integrated Mountain Development, Carl Duisberg Gesellschaft E.
V., and United Nations Environment Programme, Berlin.

Arita, K., 1983, Origin of the inverted metamorphism of the Lower Himalayas, Central Nepal. Tectonophysics, v. 95, pp. 43-60.

https://doi.org/10.1016/0040-1951(83)90258-5

Brunel, M. and Kienast, J.R., 1986, Etude petro-structurale des chevauchements ductiles Himalayens sur la transversale de l'Everest-Makalu (Nepal oriental). Canadian Journal of Earth Science, v. 23, pp. 1117-1137.

https://doi.org/10.1139/e86-111

Caby, R., Pécher, A., and Le Fort, P., 1983, Le grand chevauchement central himalayen: nouvelles données su le métamorphisme inverse à la base de la Dalle du Tibet. Revue de Géographie physique et de Géologie Dynamique, Paris, v. 24, pp. 89-100.

Colchen, M., Le Fort, P., and Pêcher, A., 1980, Carte géologique Annnapurna-Manaslu Ganesh, Himalaya du Népal. Echelle 1:200,000. Centre National de la Recherche Scientifique, Paris.

Colchen, M., Le Fort, P., and Pêcher, A., 1986, Researches géologiques dans 1'Himalaya du Népal. AnnapurnaManaslu-Ganesh, Paris, Centre de Researches Paris (in French and English). 136 p.

Dhital, M.R., 2015, Geology of the Nepal Himalaya: Regional perspective of the classic collided orogen. Springer Cham Heidelberg, New York, Dordrecht London, 498 p.

Gansser, A., 1964, Geology of the Himalaya. Interscience Publisher, London, 289 p.

Hodges, K.V., Hubbard, M.S., and Silverberg, D.S., 1988, Metamorphic constraints on the thermal evolution of the central Himalayan Orogen. Philosophical Transactions of the Royal Society of London, v. A326, pp. 257-280.

https://doi.org/10.1098/rsta.1988.0087

Hodges, K.V., Parrish, R.R., and Searle, M.P., 1996, Tectonic evolution of the central Annapurna Range, Nepalese Himalaya. Tectonics, v. 15, pp. 1264-1291.

https://doi.org/10.1029/96TC01791

Hubbard, M., 1989, Thermobarometric constraints on the thermal history of the Main Central Thrust Zone and Tibetan Slab, Eastern Nepal. Journal of Metamorphic Geology, v. 7, pp. 19-30.

https://doi.org/10.1111/j.1525-1314.1989.tb00572.x

Hubbard, M.S. and Harrison, T.M., 1989, 40Ar/39Ar age constraints on deformation and metamorphism in the Main Central Thrust zone and Tibetan Slab, eastern Nepal Himalaya. Tectonics, v. 8, pp. 865-880.

https://doi.org/10.1029/TC008i004p00865

Le Fort, P., 1975, Himalayas, the collided range: Knowledge of the continental arc. American Journal of Science. v. 275A, pp. 1-44. 
Le Fort, P., Pecher, A., and Upreti, B.N., 1986, A section through the Tibetan Slab in central Nepal (Kali Gandaki valley): mineral chemistry and thermobarometry. In: Evolution des domaines orogeniques d'Asie meridionale (de la Turquie a l'Indonesie). (edited by Le Fort, P., Colchen, M., and Montenat, C.), Memoires des Science de la Terre, Nancy, v. 47, pp. 211-228.

Macfarlane, A.M., 1995, An evaluation of the inverted metamorphic gradient at Langtang National Park, Central Nepal Himalaya. Journal of Metamorphic Geology, v. 13, pp. 595-612.

https://doi.org/10.1111/j.1525-1314.1995.tb00245.x

Ohta, Y., Akiba, C., Arita, K., and Maruo, Y., 1973, Geology of the Nepal Himalayas. Pokhara-Gorkha Region. In: Ohta Y, Akiba C. (eds. Hashimoto, S.), Himalayan Committee of Hokkaido University, Sapporo, pp. 159188.

Paudel, L.P. and Arita, K., 2000. Tectonic and polymetamorphic history of the Lesser Himalaya in central Nepal. Journal of Asian Earth Sciences, v. 18, pp. 561-584.

https://doi.org/10.1016/S1367-9120(99)00069-3

Paudyal, K.R. and Paudel, L.P., 2011. Geological setting and lithostratigraphy of the Lesser Himalaya in the MuglingBanspani area, central Nepal. Journal of Nepal Geological Society, v. 42, pp. 51-64.

Paudyal, K.R., 2018, Thin skinned tectonics and deformation history of Lesser Himalaya of Nepal: study from MuglingDamauli area. Journal of Academic Research (University Campus, Tribhuvan University), v. 1, pp. 23-28.

Pêcher, A., 1977, Geology of the Nepal Himalaya: deformation and petrography in the Main Central Thrust zone. Ecologie et geologie de 1' Himalaya, Colloques Internationaux du Centre National de la Recherche Scientifique, Paris, v. 268A, pp. 301-318.

Pêcher, A., 1978, Déformations et métamorphisme associes à une zone de cisaillement. Exemple du grand chevauchement central himalayen (MCT), transversale des Annapurna et du Manaslu, Népal. Ph. D. thesis, Grenoble, 310p.

Pêcher, A., 1989, The metamorphism in Central Himalaya.
Journal of Metamorphic Geology, v. 7, pp. 31- 41. https://doi.org/10.1111/j.1525-1314.1989.tb00573.x

Rai, S.M., Guillot, S., Le Fort, P., and Upreti, B.N., 1998, Pressure-temperature evolution in the Kathmandu and Gosainkund regions, Central Nepal. Journal of Asian Earth Sciences, v. 16, pp. 283-298.

https://doi.org/10.1016/S0743-9547(98)00019-1

Rai, S.M., Upreti, B.N., Yoshida, M., Bhattarai, T.N., Ulak, P.D., Dahal, R.K., Dhakal, S., Gajurel, A.P., and Koirala, M.P., 2005, Geology of the Lesser and Higher Himalayan zones along the Kaligandaki Valley, central-west Nepal Himalaya. Proceeding of JICA Regional Seminar on National Disaster, Kathmandu, Nepal, pp. 43-56.

Sakai, H., 1985, Geology of the Kali Gandaki supergroup of the Lesser Himalaya in Nepal. Memoirs of the Faculty of Science, Kyushu University (Japan), Series D, Geology, v. 25, pp. 337-397.

Schelling, D. and Arita, K., 1991, Thrust tectonics, crustal shortening, and the structure of the far-eastern Nepal Himalaya. Tectonics, v. 10, pp. 851-862.

https://doi.org/10.1029/91TC01011

Srivastava, P. and Mitra, G., 1994, Thrust geometries and deep structure of the outer and lesser Himalaya, Kumaon and Garhwal (India): implications for evolution of the Himalayan fold-and-thrust belt. Tectonics, v. 13(1), pp. 89-109.

$$
\text { https://doi.org/10.1029/93TC01130 }
$$

Stöcklin, J., 1980, Geology of Nepal in its regional frame. Journal of Geological Society of London, v. 137, pp. 1-34. https://doi.org/10.1144/gsjgs.137.1.0001

Stöcklin, J. and Bhattarai, K.D., 1977, Geology of Kathmandu area and central Mahabharat range, Nepal Himalaya. Report of Department of Mines and Geology, Kathmandu, United Nation Development Program (unpublished), 86p.

Vannay, J.C. and Hodges, K.V., 1996, Tectonometamorphic evolution of the Himalayan metamorphic core between the Annapurna and Dhaulagiri, central Nepal. Journal of Metamorphic Geology, v. 14, pp. 635-656. 